\title{
Synthesis and Antimicrobial Activity of Some New 5-(Pyridin-4-yl)-3-thioacetamido-1,2,4-triazole
}

\author{
M.KARAARSLAN ${ }^{1}$, P.KOPARIR ${ }^{2 *}$, A.CANSIZ ${ }^{3}$, C.OREK $^{3}$ and O.SAP ${ }^{3}$ \\ ${ }^{1}$ Department of Chemistry, Forensic Medicine Institute, TR-4400, Malatya, Turkey \\ ${ }^{2}$ Department of Chemistry, Aksaray, Universty, TR-68100, Aksaray, Turkey \\ ${ }^{3}$ Department of Chemistry, Firat, University, TR-23119 Elazığ, Turkey \\ pelin.kutulay@adalet.gov.tr
}

Received 7 May 2012 / Accepted 18 May 2012

\begin{abstract}
A series of 5-(pyridin-4-yl)-3-thioacetamide-1,2,4-triazoles (4a-o), was synthesized, characterized and evaluated for screening antibacterial and antifungal activities on microorganisms, respectively on five bacteria and and candida tropicalis. The structures of original compounds were confirmed by analytical and spectroscopic (FT-IR, ${ }^{1} \mathrm{H}$ NMR and ${ }^{13} \mathrm{C}$ NMR) methods and elemental analysis. Both the antibacterial and antifungal activities and MIC values of compounds were reported. Among the tested compounds, the most effective compound providing a MIC values of $64 \mu \mathrm{g} \mathrm{mL} \mathrm{m}^{-1}$ are $\mathbf{4 a , b}$ aganist $B$. subtilis and $S$. typhimurium and $\mathbf{4 o}$ against $E$. coli only.
\end{abstract}

Keywords: Triazole, Acetamido, Antimicrobial activity

\section{Introduction}

Triazole derivatives are the other major chemical group of antifungal azole derivatives. Nowadays, the most frequently used triazoles are fluconazole and itraconazole. They posses a broad spectrum of antifungal activity and reduced toxicity when compared the imidazole antifungals ${ }^{1-6}$.

The ring-closure reactions of carbohydrazides are well-known and have been thoroughly studied, In these reactions five-membered heterocycles with three heteroatoms such as are formed, 1,3,4-oxadiazoles, 1,3,4-thiadiazole and 1,2,4-triazoles ${ }^{7-9}$.

Substituted 1,2,4-triazoles have also been actively studied as bridging ligands coordinating through their vicinal $\mathrm{N}$ atoms and some have special structure with interesting magnetic properties ${ }^{10}$. In addition there are some studies on electronic structures and thiolthione tautomeric on equilibrium of heterocyclic thione derivatives ${ }^{11-13}$.

Acetanilide derivatives are reported to exhibit a number of biological activities, including anesthetic ${ }^{14}$, antipyretic ${ }^{15}$, antiinflammatory ${ }^{16}$ and antibacterial ${ }^{17-19}$ effects. Substitutions including thio ${ }^{20,21}$ alkylthio and alkenylthio ${ }^{22,23}$ derivates have been carried out primarily at the 3-position of the 1,2,4-triazole ring, as potential antimicrobial agents that will overcome the above mentioned resistance problems. Based on these findings, the present paper deals with the synthesis, characterization and preliminary antimicrobial activity evaluation of some new substances containing triazole rings. 


\section{Experimental}

1a-c, 2a-e, 3a-e and 4a-o compounds were prepared following literature procedures ${ }^{24-26,13}$, respectively. Melting points were determined on a Thomas Hoover melting point apparatus and are uncorrected, but checked by differential scanning calorimetry (DSC). The IR spectra were registered with a Mattson 1000 FT-IR specrtaphotometer. The NMR spectra were recorded on Varian Gemini $200 \mathrm{MHz}$ and Jeol FX-90Q spectrometers and are reported in ppm $(\delta)$ relative to tetramethysilane as the internal Standard $\left({ }^{1} \mathrm{H}\right)$ or deuterochloroform $\left(\mathrm{C}^{13} \mathrm{NMR}\right.$ 75,5, 49,5 and 22,4 MHz). Elemental analyses were done on ALECOCHNS-938. Starting chemicals were obtained from Merck or Aldrich.

The synthetic route of compounds is outlined in (Scheme 1). In the present work, 2-chloro- $N$-(aryl/alkyl)acetamides (1a-c) were prepared for the first time by reacting $\left(\mathrm{R}_{1}-\mathrm{NH}_{2}\right)$ amines with chloroacetyl chloride in accordance with the method described in the literature ${ }^{24,25}$. The condensation of the acid hydrazide with appropriate aryl/alkyl isothiocyanate resulted in formation of thiosemicarbazides (2a-e).
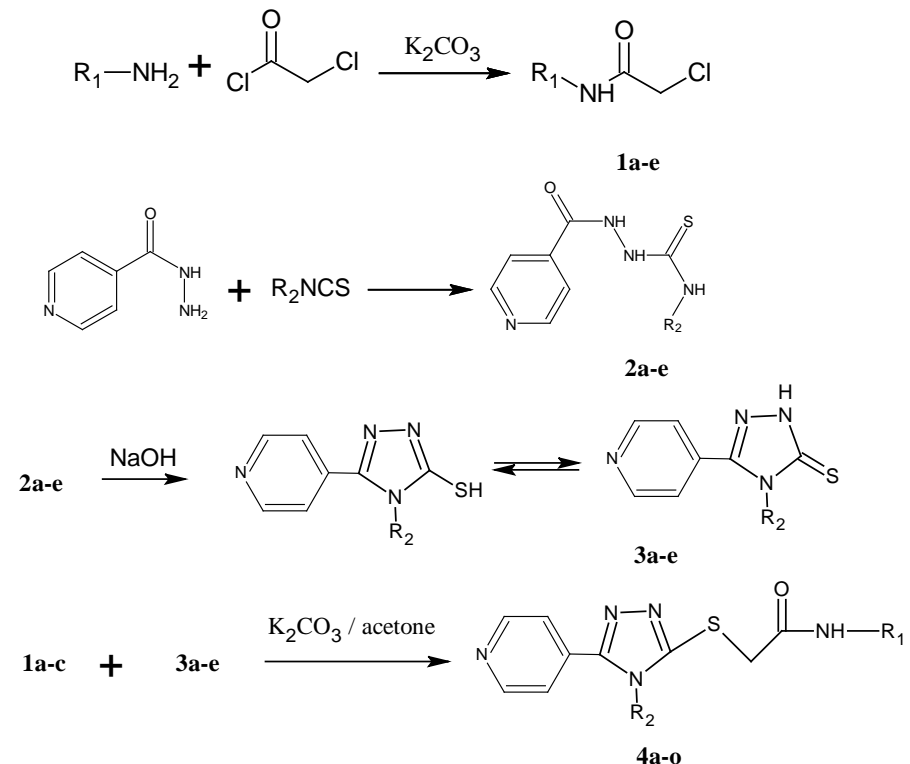

\section{Scheme 1}

The thiosemicarbazides (2a-e), on refluxing with $2 \mathrm{~N}$ sodium hydroxide solution were cyclized into corresponding 5-(pyridin-4-yl)-3H-1,2,4-triazole-3-thiole (3a-e). Treatment of equimolar quantities of these triazoles (3a-e) with 2-chloro- $N$-(aryl/alkyl) acetamides (1a-c) in the presence of anhydrous potassium carbonate resulted in the formation of the title compounds (4a-o). The characterization data of compounds (4a-o) are given in the Table $1 \& 2$.

\section{General method for the synthesis of compounds (1a-c)}

An ice-cooled solution of $\mathrm{R}_{1}-\mathrm{NH}_{2}(0.05 \mathrm{~mol})$ in acetone was added chloroacetylchloride ( $0.05 \mathrm{~mol}$ in acetone) dropwise and then the solution was kept for $2 \mathrm{~h}$ at room temperature. The resulting mixture was poured in ice-cold water and the shiny crystalline product was collected and filtered. 
Table 1. Physical data of the prepared compounds 4(a-o)

\begin{tabular}{|c|c|c|c|c|c|c|}
\hline ن̈. & $\mathrm{R}_{1}$ & $\mathrm{R}_{2}$ & ${ }^{\mathrm{M} . \mathrm{p} .}$ & 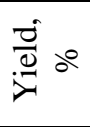 & $\begin{array}{l}\text { Empirical } \\
\text { formula }\end{array}$ & $\begin{array}{l}\text { Calcd. } \\
\text { (Found)\% } \\
\text { CHN }\end{array}$ \\
\hline $4 a$ & Cyclohexyl & Benzyl & $\begin{array}{l}119- \\
120\end{array}$ & 75 & $\mathrm{C}_{22} \mathrm{H}_{25} \mathrm{~N}_{5} \mathrm{OS}$ & $\begin{array}{c}64.84(64.88) ; \\
\text { 6.18(6.21); } \\
\text { 17.18(17.19) }\end{array}$ \\
\hline 4b & & Ethyl & $91-92$ & 83 & $\mathrm{C}_{17} \mathrm{H}_{23} \mathrm{~N}_{5} \mathrm{OS}$ & $\begin{array}{c}\text { 59.10(59.13); } \\
\text { 6.71(6.73); } \\
20.27(20.31)\end{array}$ \\
\hline 4c & & Phenyl & $\begin{array}{l}208- \\
209\end{array}$ & 78 & $\mathrm{C}_{21} \mathrm{H}_{23} \mathrm{~N}_{5} \mathrm{OS}$ & $\begin{array}{c}64.10(64.14) \\
5.89(5.92), \\
17.80(17.82)\end{array}$ \\
\hline 4d & & Allyl & $\begin{array}{l}241- \\
242\end{array}$ & 85 & $\mathrm{C}_{18} \mathrm{H}_{23} \mathrm{~N}_{5} \mathrm{OS}$ & $\begin{array}{c}\text { 60.48(60.47); } \\
\text { 6.49(6.53); } \\
\text { 19.59(19.62) }\end{array}$ \\
\hline $4 e$ & & $\begin{array}{c}4- \\
\text { methylphenyl }\end{array}$ & $\begin{array}{l}170- \\
171\end{array}$ & 69 & $\mathrm{C}_{22} \mathrm{H}_{25} \mathrm{~N}_{5} \mathrm{OS}$ & $\begin{array}{c}\text { 64.84(64.86); } \\
\text { 6.18(6.22); } \\
\text { 17.18(17.23) }\end{array}$ \\
\hline $\mathbf{4 f}$ & $\begin{array}{c}\text { 4- } \\
\text { chlorophenyl }\end{array}$ & Benzyl & $\begin{array}{l}173- \\
174\end{array}$ & 68 & $\mathrm{C}_{22} \mathrm{H}_{17} \mathrm{ClN}_{5} \mathrm{OS}$ & $\begin{array}{c}\text { 60.61(60.63); } \\
\text { 4.16(4.14); } \\
\text { 16.07(16.10) }\end{array}$ \\
\hline $4 g$ & & Ethyl & $\begin{array}{l}176- \\
177\end{array}$ & 65 & $\mathrm{C}_{17} \mathrm{H}_{16} \mathrm{ClN}_{5} \mathrm{OS}$ & $\begin{array}{c}\text { 54.61(54.64); } \\
\text { 4.31(4.28); } \\
\text { 18.73(18.74) }\end{array}$ \\
\hline $4 h$ & & Phenyl & $\begin{array}{l}211- \\
212\end{array}$ & 71 & $\mathrm{C}_{21} \mathrm{H}_{16} \mathrm{ClN}_{5} \mathrm{OS}$ & $\begin{array}{c}\text { 59.78(59.80); } \\
\text { 3.82(3.85); } \\
16.60(16.59)\end{array}$ \\
\hline $4 i$ & & Allyl & $\begin{array}{l}261- \\
262\end{array}$ & 81 & $\mathrm{C}_{18} \mathrm{H}_{16} \mathrm{ClN}_{5} \mathrm{OS}$ & $\begin{array}{c}\text { 56.63(56.65); } \\
\text { 4.18(4.20), } \\
\text { 18.15(18.14) }\end{array}$ \\
\hline $4 j$ & & $\begin{array}{c}\text { 4- } \\
\text { methylphenyl }\end{array}$ & $\begin{array}{l}226- \\
227\end{array}$ & 78 & $\mathrm{C}_{22} \mathrm{H}_{18} \mathrm{ClN}_{5} \mathrm{OS}$ & $\begin{array}{c}\text { 60.61(60.63); } \\
\text { 4.16(4.20); } \\
\text { 16.07(16.09) }\end{array}$ \\
\hline $4 k$ & $\begin{array}{c}\text { 4- } \\
\text { nitrophenyl }\end{array}$ & Benzyl & $\begin{array}{l}191- \\
192\end{array}$ & 63 & $\mathrm{C}_{22} \mathrm{H}_{18} \mathrm{~N}_{6} \mathrm{O}_{3} \mathrm{~S}$ & $\begin{array}{c}\text { 59.18(59.22); } \\
\text { 4.06(4.05); } \\
\text { 18.82(18.85) }\end{array}$ \\
\hline 41 & & Ethyl & $\begin{array}{l}187- \\
188\end{array}$ & 79 & $\mathrm{C}_{17} \mathrm{H}_{16} \mathrm{~N}_{6} \mathrm{O}_{3} \mathrm{~S}$ & $\begin{array}{c}\text { 53.12(53.14); } \\
\text { 4.20(4.21); } \\
\text { 21.86(21.87) }\end{array}$ \\
\hline $4 m$ & & Phenyl & $\begin{array}{l}151- \\
153\end{array}$ & 77 & $\mathrm{C}_{21} \mathrm{H}_{16} \mathrm{~N}_{6} \mathrm{O}_{3} \mathrm{~S}$ & $\begin{array}{c}\text { 58.32(58.34); } \\
\text { 3.73(3.74); } \\
\text { 19.43(19.42) }\end{array}$ \\
\hline $4 n$ & & Allyl & $\begin{array}{l}251- \\
252\end{array}$ & 66 & $\mathrm{C}_{18} \mathrm{H}_{16} \mathrm{~N}_{6} \mathrm{O}_{3} \mathrm{~S}$ & $\begin{array}{c}\text { 54.54(54.55); } \\
\text { 4.07(4.05); } \\
\text { 21.20(21.21) }\end{array}$ \\
\hline 40 & & $\begin{array}{c}\text { 4- } \\
\text { methylphenyl }\end{array}$ & $\begin{array}{c}247- \\
248\end{array}$ & 73 & $\mathrm{C}_{22} \mathrm{H}_{18} \mathrm{~N}_{6} \mathrm{O}_{3} \mathrm{~S}$ & $\begin{array}{c}\text { 59.18(59.16); } \\
\text { 4.06(4.07); } \\
\text { 18.82(18.85) }\end{array}$ \\
\hline
\end{tabular}


Table 2. Spectral data of the prepared compounds 4a-o

\begin{tabular}{|c|c|c|}
\hline Compd & $\begin{array}{l}\text { IR (KBr): v } \\
\left(\mathrm{cm}^{-1}\right)\end{array}$ & ${ }^{1} \mathrm{H}-\mathrm{NMR} \delta(\mathrm{ppm})$ \\
\hline $4 a$ & $\begin{array}{l}1668(\mathrm{C}=\mathrm{O}) \\
1614(\mathrm{C}=\mathrm{N})\end{array}$ & $\begin{array}{l}\text { 7.00-8.69 }(\mathrm{m}, 10 \mathrm{H}, \mathrm{Ar}-\mathrm{H} \text { and }-\mathrm{NH}), 5.22\left(\mathrm{~s}, 2 \mathrm{H},-\mathrm{N}-\mathrm{CH}_{2}\right) \text {, } \\
3.84\left(\mathrm{~s}, 2 \mathrm{H}, \mathrm{S}-\mathrm{CH}_{2}\right), 3.76-3.78 \\
(\mathrm{~m}, 1 \mathrm{H}, \text { cyclohexyl }-\mathrm{N}-\mathrm{CH}), 1.23-1.84(\mathrm{~m}, 10 \mathrm{H} \text {, } \\
\left.\text { cyclohexyl- } \mathrm{CH}_{2}\right) \text {. }\end{array}$ \\
\hline $4 \mathbf{b}$ & $\begin{array}{l}1670(\mathrm{C}=\mathrm{O}) \\
1610(\mathrm{C}=\mathrm{N})\end{array}$ & $\begin{array}{l}\text { 7.25-8.81 (m, 5H, Ar-H and }-\mathrm{NH}), 4.03-4.09(\mathrm{q}, 13 \mathrm{H},- \\
\left.\mathrm{CH}_{2}-\mathrm{CH}_{3}\right), 3.85\left(\mathrm{~s}, 2 \mathrm{H},-\mathrm{S}-\mathrm{CH}_{2}\right), 3.82-3.83(\mathrm{~m}, 1 \mathrm{H} \text {, } \\
\text { cyclohexyl }-\mathrm{N}-\mathrm{CH}), 1.25-1.86\left(\mathrm{~m}, 13 \mathrm{H},-\mathrm{CH}_{2}-\mathrm{CH}_{3} \text {, and }\right. \\
\left.\text { cyclohexyl- } \mathrm{CH}_{2}\right) \text {. }\end{array}$ \\
\hline 4c & $\begin{array}{l}1658(\mathrm{C}=\mathrm{O}) \\
1614(\mathrm{C}=\mathrm{N})\end{array}$ & $\begin{array}{l}\text { 7.24-8.56 (m, 10H, Ar-H, and -NH), } 3.85\left(\mathrm{~s}, 2 \mathrm{H}, \mathrm{S}-\mathrm{CH}_{2}\right) \text {, } \\
\text { 3.79-3.82 (m, 1H, , cyclohexyl -N-CH), 1.25-1.188 (m, } \\
\left.\text { 10H, cyclohexyl- } \mathrm{CH}_{2}\right) \text {. }\end{array}$ \\
\hline 4d & $\begin{array}{l}1675(\mathrm{C}=\mathrm{O}) \\
1609(\mathrm{C}=\mathrm{N})\end{array}$ & 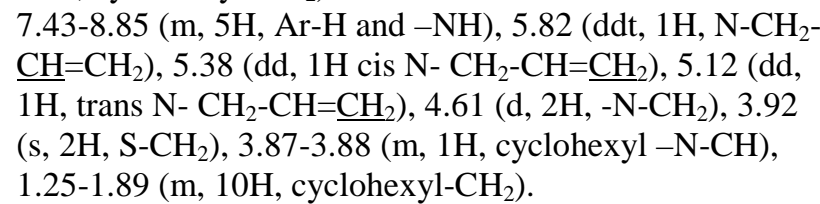 \\
\hline $4 e$ & $\begin{array}{l}1678(\mathrm{C}=\mathrm{O}) \\
1618(\mathrm{C}=\mathrm{N})\end{array}$ & $\begin{array}{l}\text { 7.11-8.57 (m, 9H, Ar-H, and -NH), } 3.78\left(\mathrm{~s}, 2 \mathrm{H},-\mathrm{S}-\mathrm{CH}_{2}\right) \text {, } \\
\text { 3.71-3.73 (m, 1H, cyclohexyl -N-CH), } 2.47\left(\mathrm{~s}, 3 \mathrm{H}, \mathrm{CH}_{3}\right) \text {, } \\
\left.\text { 1.25-1.89 (m, 10H, cyclohexyl- } \mathrm{CH}_{2}\right) \text {. }\end{array}$ \\
\hline 4f & $\begin{array}{l}1660(\mathrm{C}=\mathrm{O}) \\
1614(\mathrm{C}=\mathrm{N})\end{array}$ & $\begin{array}{l}10.43(\mathrm{br}, 1 \mathrm{H},-\mathrm{NH}), 7.06-8.72(\mathrm{~m}, 13 \mathrm{H}, \mathrm{Ar}-\mathrm{H}), 5.31 \text { (s, } \\
2 \mathrm{H},-\mathrm{N}^{\left.-\mathrm{CH}_{2}\right), 3.99}\left(\mathrm{~s}, 2 \mathrm{H}, \mathrm{S}-\mathrm{CH}_{2}\right)\end{array}$ \\
\hline $4 g$ & $\begin{array}{l}1680(\mathrm{C}=\mathrm{O}) \\
1613(\mathrm{C}=\mathrm{N})\end{array}$ & $\begin{array}{l}10.51(\mathrm{~s}, 1 \mathrm{H},-\mathrm{NH}), 7.20-8.83(\mathrm{~m}, 8 \mathrm{H}, \mathrm{Ar}-\mathrm{H}), 3.97-4.09 \\
\left(\mathrm{~m}, 4 \mathrm{H}, \mathrm{S}-\mathrm{CH}_{2} \text { and }-\mathrm{CH}_{2}-\mathrm{CH}_{3}\right), 1.44\left(\mathrm{t}, 3 \mathrm{H}, \mathrm{CH}_{2}-\mathrm{CH}_{3}\right) .\end{array}$ \\
\hline $4 h$ & $\begin{array}{l}1660(\mathrm{C}=\mathrm{O}) \\
1614(\mathrm{C}=\mathrm{N})\end{array}$ & $\begin{array}{l}10.66(\mathrm{br}, 1 \mathrm{H},-\mathrm{NH}), 7.05-8.54(\mathrm{~m}, 13 \mathrm{H}, \mathrm{Ar}-\mathrm{H}), 4.21(\mathrm{~s}, \\
\left.2 \mathrm{H}, \mathrm{S}-\mathrm{CH}_{2}\right) .\end{array}$ \\
\hline $4 \mathbf{i}$ & $\begin{array}{l}1674(\mathrm{C}=\mathrm{O}) \\
1617(\mathrm{C}=\mathrm{N})\end{array}$ & $\begin{array}{l}10.23(\mathrm{br}, 1 \mathrm{H},-\mathrm{NH}), 7.27-8.66(\mathrm{~m}, 8 \mathrm{H}, \mathrm{Ar}-\mathrm{H}), 6.11(\mathrm{ddt}, \\
\left.1 \mathrm{H}, \mathrm{N}-\mathrm{CH}_{2}-\mathrm{CH}=\mathrm{CH}_{2}\right), 5.27\left(\mathrm{dd}, 1 \mathrm{H}, \mathrm{cis} \mathrm{N}-\mathrm{CH}_{2^{-}}\right. \\
\left.\mathrm{CH}=\mathrm{CH}_{2}\right), 5.09\left(\mathrm{dd}, 1 \mathrm{H} \text {, trans N- } \mathrm{CH}_{2}-\mathrm{CH}=\mathrm{CH}_{2}\right), 4.69(\mathrm{~d}, \\
\left.2 \mathrm{H},-\mathrm{N}^{-} \mathrm{CH}_{2}\right), 3.91\left(\mathrm{~s}, 2 \mathrm{H}, \mathrm{S}-\mathrm{CH}_{2}\right) .\end{array}$ \\
\hline $4 \mathbf{j}$ & $\begin{array}{l}1659(\mathrm{C}=\mathrm{O}) \\
1615(\mathrm{C}=\mathrm{N})\end{array}$ & $\begin{array}{l}10.40(\mathrm{~s}, 1 \mathrm{H},-\mathrm{NH}), 7.13-8.58(\mathrm{~m}, 12 \mathrm{H}, \mathrm{Ar}-\mathrm{H}), 3.94(\mathrm{~s}, \\
\left.2 \mathrm{H}, \mathrm{S}-\mathrm{CH}_{2}\right)\end{array}$ \\
\hline $4 \mathbf{k}$ & $\begin{array}{l}1674(\mathrm{C}=\mathrm{O}) \\
1614(\mathrm{C}=\mathrm{N})\end{array}$ & $\begin{array}{l}10.19 \text { (br, } 1 \mathrm{H},-\mathrm{NH}), 7.11-8.87(\mathrm{~m}, 13 \mathrm{H}, \mathrm{Ar}-\mathrm{H}), 5.29 \\
\left(\mathrm{~s}, 2 \mathrm{H},-\mathrm{N}-\underline{\mathrm{CH}}_{2}\right), 3.95\left(\mathrm{~s}, 2 \mathrm{H}, \mathrm{S}-\mathrm{CH}_{2}\right) .\end{array}$ \\
\hline 41 & $\begin{array}{l}1678(\mathrm{C}=\mathrm{O}) \\
1617(\mathrm{C}=\mathrm{N})\end{array}$ & $\begin{array}{l}10.23(\mathrm{br}, 1 \mathrm{H},-\mathrm{NH}), 7.47-8.87(\mathrm{~m}, 8 \mathrm{H}, \mathrm{Ar}-\mathrm{H}), 4.15(\mathrm{q} \text {, } \\
\left.2 \mathrm{H},-\mathrm{CH}_{2}-\mathrm{CH}_{3}\right), 3.87\left(\mathrm{~s}, 2 \mathrm{H}, \mathrm{S}-\mathrm{CH}_{2}\right), 1.41\left(\mathrm{t}, 3 \mathrm{H}, \mathrm{CH}_{2^{-}}\right. \\
\left.\mathrm{CH}_{3}\right) .\end{array}$ \\
\hline $4 m$ & $\begin{array}{l}1665(\mathrm{C}=\mathrm{O}) \\
1619(\mathrm{C}=\mathrm{N})\end{array}$ & $\begin{array}{l}10.33(\mathrm{br}, 1 \mathrm{H},-\mathrm{NH}), 7.25-8.88(\mathrm{~m}, 13 \mathrm{H}, \mathrm{Ar}-\mathrm{H}), 3.95(\mathrm{~s}, \\
\left.2 \mathrm{H}, \mathrm{S}-\mathrm{CH}_{2}\right) .\end{array}$ \\
\hline $4 n$ & $\begin{array}{l}1648(\mathrm{C}=\mathrm{O}) \\
1616(\mathrm{C}=\mathrm{N})\end{array}$ & $\begin{array}{l}10.31(\mathrm{br}, 1 \mathrm{H},-\mathrm{NH}), 7.568 .64(\mathrm{~m}, 8 \mathrm{H}, \mathrm{Ar}-\mathrm{H}), 6.21 \text { (ddt, } \\
\left.1 \mathrm{H}, \mathrm{N}-\mathrm{CH}_{2}-\mathrm{CH}=\mathrm{CH}_{2}\right), 5.28\left(\mathrm{dd}, 1 \mathrm{H}, \mathrm{cis} \mathrm{N}-\mathrm{CH}_{2^{-}}\right. \\
\left.\mathrm{CH}=\mathrm{CH}_{2}\right), 5.05\left(\mathrm{dd}, 1 \mathrm{H} \text {, trans N- } \mathrm{CH}_{2}-\mathrm{CH}=\mathrm{CH}_{2}\right), 4.74(\mathrm{~d}, \\
\left.2 \mathrm{H},-\mathrm{N}^{-} \mathrm{CH}_{2}\right), 3.89\left(\mathrm{~s}, 2 \mathrm{H}, \mathrm{S}-\mathrm{CH}_{2}\right) .\end{array}$ \\
\hline 40 & $\begin{array}{l}1665(\mathrm{C}=\mathrm{O}) \\
1620(\mathrm{C}=\mathrm{N})\end{array}$ & $\begin{array}{l}10.11(\mathrm{br}, 1 \mathrm{H},-\mathrm{NH}), 7.19-8.72(\mathrm{~m}, 12 \mathrm{H}, \mathrm{Ar}-\mathrm{H}), 3.96(\mathrm{~s}, \\
\left.2 \mathrm{H}, \mathrm{S}-\mathrm{CH}_{2}\right), 2.39\left(\mathrm{~s}, 3 \mathrm{H}, \mathrm{CH}_{3}\right) .\end{array}$ \\
\hline
\end{tabular}




\section{General method for the synthesis of compounds (2a-e)}

0.01 Mole of isonicotinohydrazide in $(50 \mathrm{~mL})$ of absolute ethanol was heated until it dissolved. 0.01 mole appropriate substituted isothiocyanate derivatives $\left(\mathrm{R}_{2} \mathrm{NCS}\right)$ was added and the mixture was refluxed for $5 \mathrm{~h}$. After the completion of the reaction, the crude product which precipitated on cooling was filtered, washed with diethyl ether, dried and crystallized with suitable solvents.

\section{General method for the synthesis of compounds (3a-e)}

A solution of ( 0.01 mole (2a-e) in $50 \mathrm{~mL} 1 \mathrm{~N} \mathrm{NaOH}$ solution was heated under reflux for $5 \mathrm{~h}$. The mixture was cooled and acidified to $\mathrm{pH} 3$ with concentrated hydrochloric acid. The precipitate was filtered and washed several times with distilled water. The pure compounds were obtained following crystallization with suitable solvents.

\section{General method for the synthesis of compounds (4a-o)}

A suspension of acetamide (1a-c) $(0.005 \mathrm{~mol})$ in acetone $(10 \mathrm{~mL})$, was added an equimolar amount of triazole (3a-e). An equimolar $\mathrm{K}_{2} \mathrm{CO}_{3}$ was added as a catalyst and the solution was stirred for $10 \mathrm{~h}$. The solid was evaporated. The residue was dispersed with water to obtain (4a-o).

In the present work, 15 new compounds (4a-o) were synthesized. The structures of them were elucidated by spectral data. When chloroacetyl chloride was added to amines in the presence of potassium carbonate, the compounds (1a-c) were obtained in $85-90 \%$ yields. Synthetic methods for preparation of the title heterocycles from the isothiocyanate adducts of hydrazides are known. The treatment of isonicotinohydrazide with isothiocyanates gave thiosemicarbazides (2a-e), respectively, in nearly quantitative yields. On thetreatment of thiosemicarbazides (2a-e), with aqueous sodium hydroxide, 1,2,4-triazole derivatives were obtained in 75-85\% yields (3a-e). The reaction of 2-chloro- $N$-(aryl/alkyl)acetamides (1a-c), 1,2,4-triazoles (3a-e) and anhydrous potassium carbonate in acetone gave the 5-(pyridin-4yl)-3-thioacetamido-1,2,4-triazoles in 63-83\% yields (4a-o).

In the IR spectrum of (4a-o), the most characteristic absorptions are at $1648-1680 \mathrm{~cm}^{-1}$ $v(\mathrm{C}=\mathrm{O}), 1609-1620 \mathrm{~cm}^{-1} v(\mathrm{C}=\mathrm{N})$. In the ${ }^{1} \mathrm{H}-\mathrm{NMR}$ spectra of compounds (4a-o), NH peaks were observed as broad at about 10.11-10.66 ppm region. In addition, compounds which are including $\mathrm{S}-\mathrm{CH}_{2}$ peaks were observed as singlets at about 3.84-4.21 ppm region. All the other aromatic and aliphatic protons were observed at expected regions.

\section{Antimicrobial activity}

For determining both antibacterial and antifungal activity, the synthesized compounds and the control drugs were dissolved in absolute dimethylsulfoxide (DMSO).Further dilutions were prepared at the required quantities of $1024,512,256,128,64,32,16,8$ and $4 \mu \mathrm{g} \mathrm{mL}^{-1}$ on the microorganisms at the concentrations studied. The stock solutions were prepared in DMSO and DMSO had no effect on the microorganisms in the concentrations studied. Antimicrobial activities of compounds were determined by using broth dilution method by the National Commitee for Clinical Laboratory Standards (CLSI). MIC which is the lowest concentration of a compound that completely inhibits microbial growth was determined by a Standard broth dilution technique adapted from the CLSI ${ }^{27,28}$.

Two Gram-positive, two Gram-negative bacteria and two yeast-like fungi were used as quality control strains. Tested microorganisms were the Gram-positive B. Subtilis ATCC 6633, S. aureus ATCC 6538 P, the Gram-negative E. Coli ATTC 25922, S. typhimurium NRRL B 4420 and the yeast-like fungi; C. globrata ATCC 66032 and C. tropicalis ATCC 13803. Ampicillin and flucanozole were used as antibiotic reference for bacteria and yeast, respectively (obtained from Firat Universty at the Department of Biology, Turkey). 
Bacterial cultures were obtained in Mueller-Hinton broth (Difco) for all the bacterial strains after $24 \mathrm{~h}$ of incubation at $37 \pm 0.1{ }^{\circ} \mathrm{C}$. The yeasts were propagated in sabouraud dextrose broth (Difco) after incubation for $24 \mathrm{~h}$ at $25 \pm 0.1{ }^{\circ} \mathrm{C}^{26}$. Testing was carried out in Mueller-Hinton broth and Sabouraud dextrose broth at $\mathrm{pH} 7.4$ for bacteria and yeast, respectively. The final inoculum size was $10^{5} \mathrm{CFU} \mathrm{mL}^{-1}$ for bacteria and fungi, respactively. Test compounds were dissolved in DMSO at an inital concentration of $1024 \mu \mathrm{g} \mathrm{mL}^{-1}$ and then were serially diluted in culture medium to $4 \mu \mathrm{g} \mathrm{mL}^{-1}$.

Test of tubes containing only inoculated broth was kept as control. Antibacterial activity was determined after incubation for $24 \mathrm{~h}$ at ${ }^{\circ} \mathrm{C}$ for bacteria and after incubation for $48 \mathrm{~h}$ at $25^{\circ} \mathrm{C}$ for the yeast. MIC was defined as the lowest concentrations of the compounds that inhibited visible growth of the microorganism. Each experiment in the antibacterial and antifungal assays was replicated twice to define the MIC values.

\section{Results and Discussion}

We have designed and synthesized novel compounds of 5-(pyridin-4-yl)-3-thioacetamido1,2,4-triazoles class in order to investigate the relationships between antimicrobial activity and structure. The minimum inhibitory concentration (MIC) of the synthesized compounds was determined against the Gram-positive Bacillus subtilis, Staphylococcus aureus, the Gramnegative Escherichia coli, Salmonella typhimurrium and the yeast Candida globrata and Candida tropicalis using a standard brothdilution technique. Their antimicrobial activity was compared to ampicillin and fluconazol as Standard drugs. All the MIC results are presented in Table 3.

Table 3. Antimicrobial activity results (MIC values in $\mu \mathrm{g} \mathrm{mL}^{-1}$ ) of synthesized compounds with the standard drugs

\begin{tabular}{ccccccc}
\hline Sample & $E . c$ & B.s & S.t & S. $a$ & C.t & C.g \\
\hline $\mathbf{4 a}$ & 128 & 64 & 64 & 1024 & 1024 & 1024 \\
$\mathbf{4 b}$ & 128 & 64 & 64 & 512 & 512 & - \\
$\mathbf{4 c}$ & 128 & 128 & 128 & 256 & 1024 & - \\
$\mathbf{4 d}$ & 256 & 256 & 256 & 512 & 1024 & - \\
$\mathbf{4 f}$ & 128 & 128 & 128 & 512 & - & - \\
$\mathbf{4 g}$ & 128 & 256 & 256 & 1024 & - & - \\
$\mathbf{4 i}$ & 256 & 256 & 256 & 512 & 512 & 512 \\
$\mathbf{4 j}$ & 256 & 256 & 256 & 512 & 512 & 1024 \\
$\mathbf{4 k}$ & 128 & 128 & 256 & 512 & 256 & 256 \\
$\mathbf{4 l}$ & 256 & 256 & 256 & 256 & 512 & - \\
$\mathbf{4 m}$ & 128 & 128 & 128 & 256 & 1024 & - \\
$\mathbf{4 n}$ & 128 & 256 & 256 & 512 & 1024 & 1024 \\
$\mathbf{4 0}$ & 64 & 256 & 256 & 256 & 512 & 512 \\
Ampicilin & 2 & 2 & 2 & 2 & - & - \\
Fuluconazol & & & & & 8 & 8
\end{tabular}

In vitro activity of the selected compounds and the reference drugs (MIC values in $\mu g \mathrm{~mL}^{-1}$ ). B.S: B. subtilis ATCC 6633, S. aureus ATCC 6538 P, E.c: E. Coli ATCC 25922, S.t: S. typhimurium NRRL B 4420, C.g: C. globrata ATTC 66032, C.t: C. tropicalis ATCC 13803

The obtained data reported that compounds were able to inhibit the growth of the selected microorganisms in vitro showing MIC values between 64 and $1024 \mu \mathrm{g} \mathrm{mL}^{-1}$. The synthesis of some compounds (4), showed some degree of antimicrobial activity against test microorganisms. Among the synthesized compounds, the most active derivative at an MIC 
values of $64 \mu \mathrm{g} \mathrm{mL} \mathrm{m}^{-1}$ are (4a,b) aganist B. subtilis and S. typhimurium and (4o) against E. coli only. Compounds (4a,b), (4o) might be dlightly more active than others against some of the test microorganisms.

Compounds (4a,b) and (4o) which having electron withdrawing substituents such as, benzyl / ethyl and 4-methylphenyl, respectively, on cyclohexyl and 4-nitro-phenyl group were found to be the most active compounds against B. Subtilis, S. typhimurium and E. Coli.

The lowest effective substances are (4d, $\mathbf{4 i}, \mathbf{4 j}$ and $\mathbf{4 l}$ ) against all the microorganisms studied. Interestingly, despite all the substances have very similar structures, their antimicrobial activities are very different.

\section{Acknowledgement}

This study was supported by FÜBAP (grand number 2001) Elazı ̆ , Turkey

\section{References}

1. $\quad$ Rubinstein E, Science, 1994, 264(5156), 195-195.

2. $\quad$ Brumfitt W and Hamilton-Miller J M T, Drug Exp Clin Res., 1994, 20(6), 215-224.

3. $\quad$ Neu H C, Science, 1992, 257(5073), 1064-1073.

4. $\quad$ Bechet K H, Draber W and Regal K, Drugs Germ., 1972, 15, 79-82.

5. $\quad$ Plamel M, Bartmana K and Regal K, Drugs Germ., 1972, 15, 103-120.

6. $\quad$ Lutwick L L and Rytel W M, J Am Med Assoc., 1979, 241, 271-272.

7. Fulop F, Seega E and Dombi C and Bernath G, J Heterocycl Chem., 1990, 27(4), 951-955.

8. Koparir M, Cetin A and Cansiz A, Molecules, 2005, 10(2), 475-480.

9. $\quad$ Cansiz A, Koparir M and Demirdag A, Molecules, 2004, 9(4), 204-212.

10. Kahn O and Martinez C, J Science, 1998, 279(5347), 44-48.

11. Cansiz A, Cetin A, Kutulay P and Koparir M, Asian J Chem., 2009, 21(1), 617-626.

12. Yildirim S O, Akkurt M, Koparir M, Cansiz A, Sekerci M and Heinemann F W, Acta Cryst., 2004, 60, o2368-o2370.

13. Dincer M, Ozdemir N, Cetin A, Keser T and Buyukgungor O, Acta Cryst., 2006, 62, o639-0642.

14. Isaeva G A, Dmitriev A V and Isaev P P, Rus J Phys Chem., 2001, 75(10), 1716-1719.

15. Pernerstorfer T, Schmid R, Bieglmayer C, Eichler H G, Kapiotis S and Jilma B, Clin Pharmacol Ther., 2000, 67, 70-75.

16. Roche J J, Cisneros G J, and Asc G, Angle Orthod., 1997, 67(3), 231-236.

17. Ahmedzade M, Cukurovali A and Koparir M, J Chem Soc Pak., 2003, 25(1), 51-55.

18. Ye C M, Wang X J and Zheng H H, J Environ Sci China., 2002, 14, 524-529.

19. Person M, Chem Abstr., 1962, 57, 9860f Fr. Pat. 1962, 1, 273.

20. Hiremath S P, Biradar J S and Kuradi S M, J Indian Chem Soc., 1984, 61(1), 74-76.

21. Kuboto H and Shinizu M, Chem Abstr., 1971, 74, 87996d Jpn. Pat. 1971, 7, 034, 384.

22. Ismaiel A M, Yousif M Y and Metwally M A, J Indian Chem., 1984, 23(5), 489-491.

23. Karatas F, Cansiz A, Kara H, Karatepe M and Koparir M, Rus J Biooarg Chem., 2005, 31(5), 499-501.

24. Koparir M, Cansiz A and Cetin A, Heteroatom Chem., 2005, 16(6), 503-506.

25. Cetin A, Cansiz A, Koparir M and Kazaz C, Org Chem Au Indian J., 2006, 2(5), 140-149.

26. Cetin A, Cansiz A and Digrak M, Heteroatom Chem., 2003, 14(4), 345-347.

27. Yildiz-Oren I, Yalcin I and Aki-Sener E, Eur J Med Chem., 2004, 39(3), 291-298.

28. National Committee for Clinical laboratory Standards (NCCLS), Methods for dilution antimicrobial susceptibility tests for bacteria that grow aerobically, Approved standad M7-A4, NCCLS, Villanova,13, PA: 1997, 25. 